\title{
Jihad \& Co.: Black Markets and Islamist Power
}

\author{
Aisha Ahmad \\ New York: Oxford University Press, 2017. 303 pages.
}

In this critically insightful and highly readable book of political ethnography, Aisha Ahmad, a political scientist at University of Toronto, seeks to explain how and why Islamist movements continue to militarily prevail and politically succeed in forming proto-states, over clan, ethnic, and/or tribal based competitions, amidst the chaos and disorder of civil wars across the contemporary Muslim world, from Mali to Mindanao. To this end, Ahmad seeks to go beyond the usual expositions that center the explanatory power of Islamist ideologies and identities, which dominate the scholarly fields of political science, international relations, security studies as well as the global public discourse shaped by journalists, politicians, and the punditry of shouting heads everywhere.

Through a deep, immersive study of power in Afghanistan and Somalia, Ahmad demonstrates the profoundly symbiotic relationship between Islamists and the local business class. While recognizing the interconnections between violent conflict and illicit trade is nothing new, Ahmad's explication of the economic logics of Islamist proto-states furnishes a novel two-stage dynamic to explain the indispensability and ubiquity of this Islamist-business alliance in conflict zones. The first is the gradual social process of conversion of the business class' worldview and practice to align them with Islamist identity formations, which is "aimed at mitigating uncertainty and improving access to markets" (xvii). Alongside this long-term socialization is a second, short-term political-economic dynamic of rapid shift in the business class's collective patronage of a new Islamist faction, based on the assumption that it will lower the cost of business. The formidable alliance between business class interests and Islamist institutions brings forth the new Islamist proto-state. Chapter one of the book adumbrates this two-stage argument and offers justifications for the two case studies, namely the Taliban in Afghanistan and the Islamic Courts Union in Somalia.

The second chapter unpacks the two-stage dynamic in detail. We learn that in modern civil wars across the Muslim world, business communities intentionally adopt ardent Islamist identities as a practical means toward building trust and lowering cost. Islamist factions, aspiring toward hegemony, offer the possibility of economic relationships that transcend 
the ethnic boundaries which limit rival factions rooted in clan, tribal, or ethno-linguistic social formations. This leads to the second, faster convergence of business-Islamist interests, wherein the Islamist groups leverage their broader social identity and economic market to offer stronger security at a lower cost. This development of an economy of scale leads the local business elites to throw their financial support behind the Islamists at a critical juncture of militant competition. Once this threshold is met, Islamist factions rapidly conquer and consolidate territories from their relatively socially constrained rivals to form a new proto-state, like the Taliban regime and the Islamic Courts Union (ICU). When we look at the timeline of their development (the Taliban in 1994 and the ICU in 2006), we notice a similar length of gestation, about 15 years of war. This similarity may be coincidental, but the political-military threshold is the same. Both societies, ravaged by civil war, reached a stalemate. At this critical juncture the positional properties of Islamist formations in the field of civil war factions gives the Islamists a decided economic (cost analysis) and social (trust building across clan/tribal identities) advantage.

Chapters three to six examine each of the two processes for the selected sites of inquiry. Thus chapters three and five, respectively, explore the long-term Islamist identity construction within the smuggling industry in the Afghanistan-Pakistan borderland, and the Somali business elites' gradual convergence with Islamists. In chapter four, Ahmad explores the second dynamic in the context of rising security costs during the Afghan civil war. Mullah Omar's Taliban provided the order and security across the borderland that had previously eluded the variety of industries. This allowed the Taliban to expand on the backs of voluntary donations, rather than extortions like their rival tribal warlords, which in turn allowed them to recruit and retain more disciplined fighters (81). The source of these donations was the business class, especially those involved in the highly lucrative transit trade, which, before the rise of Taliban, paid immense opportunity cost at the hands of rapacious local and tribal warlord fiefdoms and bandits. Instead of the multitude of checkpoints crisscrossing southern Afghanistan and the borderlands, the Taliban presented a simplified administration. While the rest of the world took notice of their repressive measures against women's mobility, education, and cultural expression, the men of the bazaar appreciated the newly acquired public safety to ply their trade and the lowered cost of doing business.

Chapter six, "The Price of Protection: The Rise of the Islamic Courts Union," demonstrates a similar mutually beneficial Islamist-business re- 
lationship emerging out of the incessant clan-based militia conflicts that had especially plagued southern Somalia since the fall of the last national government in 1991. Businesspeople, whether they were tycoons or small business owners, had to pay two types of tax. First was what was owed to the local racket or warlord, and the second was to the ever-fragmenting sub-clan militias and their checkpoints on the intercity highways. Unlike their rival, the Transitional Federal Government (TGF), ICU forged their supra-clan institutional identity through a universalist legal discourse and practice rooted in Islamic law and ethics. They united the courts and their associated clan-based militias, including al-Shabaab. Ahmad demonstrates, through a synthesis of secondary literature and original political ethnography, the economic logics of ICU's ability to overcome the threshold of material and social support needed to establish the rule of law and a far-reaching functioning government.

If the Taliban and the ICU had solved the riddle of creating order and security to create hegemonic proto-states, then what was their downfall? Chapter seven gives us an account of the international interventions that caused the collapse of the two proto-states. In the aftermath of their destruction, the internationally supported regimes that replaced them, despite immense monetary and military aid, have failed to gain the same level of legitimacy across Afghanistan and Somalia. In chapter eight, Ahmad expands the scope of analysis to North/Western Africa (Al-Qaeda in the Islamic Maghrib: AQIM), Middle East (Islamic State in Iraq and Syria: ISIS), and South Asia (Tahrik-i Taliban-i Pakistan: TTP).

At the time of this book's publication, these movements were not yet, as Ahmad posits, closed cases like the Taliban and the ICU. Thus, the data from this chapter's comparative survey furnishes suggestive arguments for Ahmad's larger thesis, namely that Islamist proto-states emerge out of a confluence of economic and security interests rather than mere ideological and identity politics. The epistemic humility of this chapter signals to this reader two lines of constructive criticism of some aspects of Ahmad's substantiation of this thesis.

First, the juxtaposing of Islamist success against their clan-/tribal identity-based rivals may be underestimating the element of ethnic solidarity in those very Islamists' political success. The most glaring case is the Taliban, which in its original formation and in its post-American invasion fragmentations, across the Durand Line, was more or less founded on a panor-tribal Pashtun social identity and economic compulsions relative to the other Afghan ethno-linguistic communities. How does one disaggregate 
the force of ethnic solidarity (even if it is only a necessary condition, rather than a cause) from economic calculus in explaining the rise of the Taliban proto-state?

The second issue in this juxtaposition is that when we compare a successful Islamist movement against socially limited ethnocentric rivals, we discount the other Islamist movements that failed. Explanations for those Islamists that failed to create a proto-state along the lines of the ICU or the Taliban, such as al-Ittihad al-Islamiyya (Somalia) or Gulbuddin Hekmatyar's Hezb-e Islami (Afghanistan), needed to be more robustly taken into account and integrated into the substantiation of Ahmad's thesis. Even in the section on ISIS, it would have been helpful to integrate the case of Jabhat al-Nusra's (an al-Qaeda affiliate in Syria) inability to create a proto-state to rival ISIS. We must ask, why do some Jihadi Islamist movements prevail against each other and why do others fail? Perhaps some of these Islamist movements appear too early to scale up their operation (i.e., they precede Ahmad's 'critical juncture'), or they were too embroiled and too partisan in the illicit trade network to fully leverage their Islamist universalism to create the trust and bonds that are the first part of Ahmad's two-stage dynamic. Possible answers would need to complement Ahmad's excellent political ethnography with deeper quantitative dives to identify the statistical variations of these critical junctures: when does the cost of warlords and mafias' domination outweigh the cost of Islamist-Jihadi movements' socially repressive but economically liberating regimes? At which point in the social evolution of society during an unending civil war do identities forged by the bonds of blood give way to those imagined through bonds of faith?

These two critical suggestions do not diminish Ahmad's highly teachable work. This book should be read by all concerned policy makers, scholars in the social sciences and humanities, and anyone who wants to go beyond 'culture talk' historical causation by ideas and identity and uncover structuralist explanations for the rise of Jihadi Islamist success in civil wars across the Muslim world. It is especially recommended for adoption in cognate courses at the undergraduate level, for its combination of erudition and readability. 